\title{
IAMJ
}

INTERNATIONAL

AYURVEDIC

MEDICAL JOURNAL

ISSN: 2320-5091

Impact Factor: 6.719

\section{A REVIEW ON THE ACTION OF AGNIKARMA}

\section{$\underline{\text { Deepshri Bais }}^{1}, \underline{\text { Balendra Singh }}^{2}, \underline{\text { Uttam Kumar Nirmalkar }}^{3}, \underline{\text { Satrupa Nirmal }}^{4}$}

${ }^{1}$ P.G. Scholar, Narayan Prasad Awasthi Government Ayurvedic College, Raipur, Raipur, Chhattisgarh, India ${ }^{2} \mathrm{HOD}$ and Professor, Narayan Prasad Awasthi Government Ayurvedic College, Raipur, Raipur, Chhattisgarh, India

${ }^{3}$ Reader, Narayan Prasad Awasthi Government Ayurvedic College, Raipur, Raipur, Chhattisgarh, India ${ }^{4}$ Lecturer, Narayan Prasad Awasthi Government Ayurvedic College, Raipur, Raipur, Chhattisgarh, India

Corresponding Author: deepshribais191@gmail.com

https://doi.org/10.46607/iamj1609112021

(Published Online: November 2021)

Open Access

(C) International Ayurvedic Medical Journal, India

Article Received: 18/09//2021 - Peer Reviewed: 04/10/2021 - Accepted for Publication: 06/10/2021

\section{Check for updates}

\section{ABSTRACT}

Ayurveda is an ancient medicinal system; the basic principle of Ayurveda is that a healthy person should maintain good health and a diseased person should be cured. Ancient Ayurvedic Acharya has mentioned various treatments in their Samhitas. e.g., medicinal, surgical etc.

Acharya Sushrata has mentioned various surgical procedures along with some para surgical procedures. Agnikar$m a$ is one of the superior anushastra karma (para surgical measure). Acharya Sushruta confidently said about Agnikarma that the disease treated by it can never occur again. In this modern era, it is performed and evolved as therapeutic burns or cauterization.

Keywords: Agnikarma, shalyakarma, dosha. 


\section{INTRODUCTION}

Agnikarma (thermal cautery) means a procedure performed with the help of fire. Agnikarma (thermal cautery) is mentioned in almost all Ayurvedic textbooks. Its curative, preventive, pain-relieving and haemostatic properties were brought to light even centuries ago. ${ }^{1}$ These same principles of Ayurveda are nowadays adopted in advanced technologies like cauterization, radiation therapy, laser therapy, diathermy etc. Clinically Agnikarma is a chief para surgical procedure used to treat various chronic diseases. ${ }^{1}$ Agnikarma (thermal cautery) performed by the well-skilled surgeon properly will give the tremendous result and improperly performed agnikarma will give rise to many severe complications. It works by imposing burns on the tissue surface with the help of different materials called Dahan upkarana as per Acharya Shushruta. The capacity of heat transmission and heat retention of each material is different. After applying all conservative treatment to the patient, surgery is the only treatment of choice for managing these diseases by modern medicines and after performing surgery still, we do not get a satisfactory result and also sometimes this modern surgical procedure will lead to various complications like organ damage, recurrence. ${ }^{2}$ Acharya Sushruta said that Agni (fire) is better than Kshara (alkali) because diseases treated by Agnikarma (thermal cautery) will never relapse and also because those diseases which are not cured by the use of medicines, sharp instruments and alkalies will be cured by fire (thermal cautery). It has other advantages like there will be not no fear of bleeding and putrification. ${ }^{3}$ Agnikarma (thermal cautery) can be done in all seasons, except Sharad (autumn) and greeshma (summer), even in these seasons, it can be done in an emergency condition, by applying counter methods i.e. body should be covered at the site where the agnikarma has to be performed with a moist cloth, cold folds and applying pastes which has a cooling effect, these counter method lighten up the effect of burn. ${ }^{4}$ The mechanism of action of Agnikarma is not well defined. Agnikarma act on a body on a multifactorial level. It is mostly manifested in a disease caused by vata and kapha, due to its tikshna (quick action), ushna (hot), sookshma (subtle), vyavayi (quick spreading), vikashi (work without being metabolised) guna (properties), it also can clear srotorodha (obstruction in channels of the body). In this article, an attempt is being made to spill the principle of agnikarma. ${ }^{5}$

\section{MATERIAL AND METHOD-}

Material- Literature is collected from different ancient Samhita, various websites and ayurvedic journals etc.

\section{Method-}

Shalyatantra is one of the eminent branches of Ayurved, which has major shalya procedures like Shalyakarma, ksharakarma, Agnikarma, raktamokshan but Agnikarma is prime among them all.

\section{Procedure -}

Before performing Agnikarma Patient should take Pichchil anna (a slimy substance). First marked the site of agnikarma. Then the affected area should be cleaned and then agnikarma is performed at the affected site till the Samayaka dagdha lakshana appear (an optimum sign of cauterization). ${ }^{6}$

After that mixture of honey or ghee should be applied to minimize the effect of burn. ${ }^{7}$

Types -Though there is no unambiguous description about the classification of agnikarma in Ayurvedic literature, still with a specific concept about its type of application following classification have been done.

\section{According to Dravyas used ${ }^{\mathbf{8}}$ -}

1. Snigdha Agnikarma- It is performed by madhu, ghrit, tailam which is used for agnikarma, and it is applied in the disease of sira, snayu, asthi.

2. Ruksha Agnikarma- This type of agnikarma is performed by pippali, shara, Shalaka, godanta used for agnikarma to treat the disease which is in twak and mamsa dhatu.

\section{According to Akriti'-}

1. Valaya - Circular Shape

2. Bindu - Dot made by the tip of shalaka

3. Vilekha - Different shapes created by shalaka.

Vilekha is further divided by Acharya Dalhana into 
three types according to the direction of line- Tiryaka (oblique), Riju (straight), vakra (zigzag)

4. Pratisarniya-Rubbing at the affected site by the side of heated shalaka.
According to Acharya Vagbhata, it can also be ${ }^{10}$

1. Ardhchandra (semilunar)

2. Swastik (shape of Hindu religious Swastik sign)

3. Ashtapada (shape of eight directions)

Sign of Agnikarma at each level- ${ }^{11}$

\begin{tabular}{|l|l|l|l|}
\hline Twak Dagdha & Mamsa Dagdha & Sirasnayu Dagdha & Sandhiasthi dagdha \\
\hline $\begin{array}{l}\text { Shabd pradurbhava (pro- } \\
\text { duction of sound) }\end{array}$ & $\begin{array}{l}\text { Kapota varnata (colour } \\
\text { of pigeon) }\end{array}$ & $\begin{array}{l}\text { Krishronnata varnata (black and } \\
\text { elevated ulcer) }\end{array}$ & $\begin{array}{l}\text { Karkashvarnata (roughness of } \\
\text { wound) }\end{array}$ \\
\hline $\begin{array}{l}\text { Durdagadhata } \\
\text { (mild swelling, Pain) }\end{array}$ & $\begin{array}{l}\text { Sravasannirodhascha (cessation } \\
\text { of Exudation) }\end{array}$ & $\begin{array}{l}\text { Asthiavarnata (lack of firm- } \\
\text { ness) }\end{array}$ \\
\hline $\begin{array}{l}\text { Twak sankocha (con- } \\
\text { striction of skin) }\end{array}$ & $\begin{array}{l}\text { Shushkasamkuchita } \\
\text { vranata (dryness of } \\
\text { constriction) }\end{array}$ & & \\
\hline
\end{tabular}

\section{Dagdha bheda/Kinds of burns- ${ }^{12}$}

1. Plusta dagdha- it has a pigmented area on the skin accompanied by a severe burning sensation.

2. Durdagdha- which is shallow and has a colour of tala phala (fruit of tala tree blue-black) with uniformly distributed.

3. Atidagdha- In which muscles are loosened up, the body is rigid, excruciating pain in vein, joints and bones accompanied with fever, burning sensation all over the body, severe thirst and unconsciousness, wound takes a long time to heal, discolouration of healed ulcer takes place.

Indication and its anushashtra of Agnikarma ${ }^{13}$-a disease like moles, warts, patches, painful crumpling body parts, headache, opthalmia, glaucoma, eyebrows, temples and forehead agnikarma should be done on an affected part by the tooth of a cow, pippali, suryakantha, excreta of goat, arrowhead, or metal rod. In a disease like concealed ulcers, filariasis, fistula, haemorrhoids, tumour, fistula, sinus and puyalasaka (a disease of the eye) Agnikarma should be done with the help of a Jambavosta (an instrument made from metal, like fruits of jambu), rods made up of gold, metal rod, copper rod, silver, iron or bronze, needles, honey, beeswax, oil, muscle fat, ghee, molasses, Agnikarma done by all these burns the muscle. In a disease like a sinus, ulcer of gums, profuse bleeding, in the disease of the eye, tearing and cutting of the vein, tendon, joints and bones branding should be done by using Jambavosta, bees-wax, molasses (jaggery), oil or ghee, needle, metal rod, it should be done on the veins etc.

Contraindication ${ }^{14}$-thermal cautery should not be done wound from which foreign body would not be removed, persons with multiple wounds, during hot seasons and perforated alimentary canal, collection of blood in the alimentary tract, those who are not suitable for caustic alkali therapy.

But in emergency conditions, it can be done after performing sheet chikitsa (cold therapies) and giving slimy food to the patient.

\section{DISCUSSION}

The use of fire in earlier days as far as prehistoric periods where heated stones were used to gain haemostasis. In Ayurved treating the skin tissue by heating, the method was very eminent. As back in 15001000 years of B.C. With the evolution of science, Agnikarma has been improved by the introduction of electricity called electrocautery. ${ }^{15}$ Much research is going to prove the effectiveness and benefit of cauterization in different diseases. A recent study has been done on low back pain, cutaneous, leishmaniasis, skin warts, epistaxis, psychiatric illness etc. ${ }^{15}$ Agnikarma eliminates Srotorodha (blockage of channels of the body) improve the mechanism of dhatvagni (tissue) through these properties relieve the symptoms. Its therapeutic heat also helps to increase the blood circulation in local area and subsides the pain by producing $\mathrm{P}$ substance. ${ }^{16}$ 
Agni (fire) consist of Ushna(hot), Tikshna (incisive), Sukshma (subtle) and ashukari (fast action) gunas, which are antagonist to Vata and kapha properties. Physical heat from hot Shalaka (rod) is transmitted to Twakdhatu (skin) in the form of therapeutic heat by creating Samyak Dagdha Vrana. ${ }^{16}$

This therapeutic heat acts in three ways. First, due to ushna, tikshna, sukshma, Ashukari guna, it cleared Srotovarodha, tranquillized the vitiated Vata and Kapha dosha and maintain their equilibrium. Secondly, it improves the Rasa Rakta Samvahana (blood circulation) at that site. The increased amount of blood circulated through that affected part snatch away the pain-producing substances and the patient feels relief from symptoms. Lastly, therapeutic heat upsurges the Dhatwagni (tissue), so proper metabolism of dhatu take place and digest the Amadosha from the affected site and encourage proper nutrition from Purva Dhatu. Thus, Asthi and Majja dhatu become steadier and more stable. So, in this way result would be seen in the patient as relief from all the symptoms. Further, it can be embraced that the therapeutic heat goes to deeper tissue like Mamsa Dhatu and Kapha dosha and in this way misdirect doshas comes to the equilibrium state, and the patient feels relief. ${ }^{17}$

\section{CONCLUSION}

Agnikarma shows immense results than any other para surgical procedure. The disease treated by $A g$ nikarma never relapse. Pain occurring anywhere in the body is due to vata dosha, Agni releases sangh of Vayu and pacifies vata so thereby pain is relieved.

Agnikarma is a simple and cost-effective method that does not require a costly instrument.

\section{REFERENCES}

1. Tripathy R. Shaithya.R., Rajeshwari, P.N., Athulya and. Senan. C.L. "A review on the action of Agnikarma", International Journal of current research." Vol. 8, Issue, 06, P.No.32319-32322, June 2016

2. Ghule J, "Role of Agnikarma in the management of various diseases: A review", Vol. 3, Issue $4^{\text {th }}$, P.No.15,2019
3. Murthy S.K.R. Sushrut Samhita, Chaukhamba orientalia Varanasi, Vol. 1, 2012, 12/3 P.No. 70

4. Murthy S.K.R. Sushrut Samita, Chaukhamba orientalia Varanasi Vol. 1, 2012, 12/5 P.N.71

5. 5. Dr. Jaya ghule, "Role of Agnikarma in the management of various diseases: A review, Vol. 3, Issue $4^{\text {th }}$, P.No.1-5, 2019

6. Murthy K.R.S. Sushruta Samhita. Chaukhamba orientalia Varanasi, Vol.1, 12/6, P.N.71, 2012.

7. Murthy S.K.R. Sushrut Samita. Chaukhamba orientalia Varanasi vol. 1, 12/13, P.N. 72, 2012

8. Murthy. S.K.R. Sushruta Samhita, Chaukhamba orientalia Varanasi, vol. 1, 12/4, P.N.70 2012.

9. Murthy. S.K.R. Sushruta Samhita, Chaukhamba orientalia Varanasi, vol. 1, 12/11, P.N.72, 2012.

10. Murthy.S. K.R, Chaukhambha orientalia Varansi, Ashtang Samgrah, 40/4, Vol. 1, 2005.

11. Murthy. S.K.R. Sushruta Samhita, Chaukhamba orientalia Varanasi, vol. 1, 12/8, P.N.71, 2012.

12. Murthy. S.K.R. Sushruta Samhita, Chaukhamba orientalia Varanasi, vol. 1, 12/16, P.N.73, 2012.

13. K.R.S. Murthy Ashtang Samgraha, Chaukhambha orientalia Varansi, Vol. 1, 40/2, P.N. 70, 2005.

14. K.R.S. Murthy Ashtang Samgraha, Chaukhambha orientalia Varansi, Vol. 1, 40/3, P.N. 71, 2005

15. Nagnath. R. S, "Critical appraisal of Agni karma and its therapeutic aspect", International research journal of pharmacy, 4 (5), 2013

16. Shubada V, Mahabaleshwar. S. "The Role of Agnikarma in musculoskeletal pain management", International Ayurvedic medical journal, P. No. 53525354, 2020.

17. Kumar V., J. Dudhamal.T. Gupta.T., Mahanta. V. “A comparative clinical study of Siravedha and Agnikarma in the management of Gridhrasi", An international Quarterly of Research in Ayurveda. 35 (3):270-276, 2014

\section{Source of Support: Nil Conflict of Interest: None Declared}

How to cite this URL: Deepshri Bais et al: A Review On The Action Of Agnikarma. International Ayurvedic Medical Journal \{online\} 2021 \{cited November 2021\} Available from:

http://www.iamj.in/posts/images/upload/2746_2749.pdf 